Original Article

\title{
Molecular Phylogenetics of Physa acuta (Pulmonata: Basommatophora): an Invasive species in Central Punjab Pakistan
}

\author{
Molecular Phylogenetics of Physa acuta (Pulmonata: Basommatophora): uma espécie \\ invasora no centro de Punjab, Paquistão
}

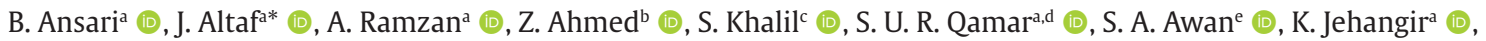

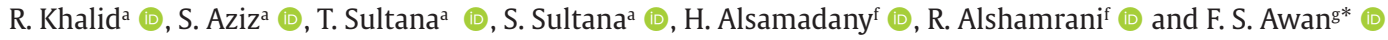 \\ aGovernment College University Faisalabad, Department of Zoology, Punjab, Pakistan \\ bUniversity of Agriculture, Center for Advanced Studies in Agriculture and Food Security - CAS-AFS, Department of Plant Breeding and \\ Genetics, Faisalabad, Pakistan \\ 'The Islamia University of Bahawalpur, Faculty of Agriculture \& Environmental Science, Department Forestry Range \& Wildlife Management, \\ Bagdad Ul Jadeed Campus, Bahawalpur, Pakistan
}

${ }^{d}$ Chulabhorn Graduate Institute, Department of Applied Biological Sciences, Lak Si, Bangkok, Thailand

eUniversity of Agriculture, Department of Computer Science, Faisalabad, Pakistan

fKing Abdulaziz University, Faculty of Science, Department of Biological Sciences, Jeddah, Saudi Arabia

gUniversity of Agriculture, Center of Agricultural Biochemistry and Biotechnology, Faisalabad, Pakistan

\begin{abstract}
Physids belong to Class Gastropoda; belong to Phylum Mollusca and being bioindicators, intermediate hosts of parasites and pests hold a key position in the ecosystem. There are three species of Genus Physa i.e. P. fontinalis, Physa acuta and P. gyrina water bodies of Central Punjab and were characterized on the basis of molecular markers High level of genetic diversity was revealed by polymorphic RAPD, however SSR markers were not amplified. The multivariate analysis revealed polymorphism ranging from 9.09 percent to 50 percent among the three Physid species. Total number of 79 loci were observed for the three species under study and 24 loci were observed to be polymorphic. These RAPD fragment(s) can be developed into co dominant markers (SCAR) by cloning and can be further sequenced for the development of the Physa species specific markers to identify the introduced and native species in Pakistan.
\end{abstract}

Keywords: mollusca, molecular marker, genetic diversity, polymorphism, physa.

\begin{abstract}
Resumo
Os físidos pertencem à classe Gastropoda; pertencem ao filo Mollusca e, sendo bioindicadores, hospedeiros intermediários de parasitas e pragas, ocupam uma posição-chave no ecossistema. Existem três espécies do gênero Physa, ou seja, $P$. fontinalis, Physa acuta e $P$. gyrina em corpos d'água do Punjab Central e foram caracterizadas com base em marcadores moleculares. Alto nível de diversidade genética foi revelado por RAPD polimórfico, no entanto os marcadores SSR não foram amplificados. A análise multivariada revelou polimorfismo variando de 9,09\% a 50\% entre as três espécies de Physid. Um número total de 79 loci foi observado para as três espécies em estudo e 24 loci foram observados como polimórficos. Esses fragmentos RAPD podem ser desenvolvidos em marcadores codominantes (SCAR) por clonagem e podem ser posteriormente sequenciados para o desenvolvimento de marcadores específicos da espécie Physa para identificar as espécies introduzidas e nativas no Paquistão.
\end{abstract}

Palavras-chave: mollusca, marcador molecular, diversidade genética, polimorfismo, physa.

\section{Introduction}

The members of the freshwater family Physidae (Pulmonata: Basommatophora) have invaded the world across all the continents, particularly freshwater lentic habitats except Antarctica. These were native to America (Wethington and Lydeard, 2007; Bousset et al., 2014) yet remained unidentified and as a result ignored which shows lesser interest of scientists (Turner \& Montgomery, 2009). The invasion history of the Physa acuta showed that it was not reported from oriental region (Ebbs et al., 2018), however Physids have been reported from Rawalpindi

*e-mail: javariaaltafuaar@yahoo.com; awanfaisal@yahoo.com

Received: December 27, 2020 - Accepted: February 11, 2021 
(Afshan et al., 2013); Baluchistan (Kakar et al., 2017) and central Punjab (Altaf et al., 2017a, b) in Pakistan. This has been recorded as an invasive species in Singapore and Thailand in past few years (Ng et al., 2018). The introduction of these three Physa species is probably much earlier than reported and has well established its population. The distribution of Physa acuta might have been facilitated by water birds or mammals (van Leeuwen et al., 2013; Bousset et al., 2013). Therefore the investigation of the pathways along with level of resource competition with other species i.e Lymnea and Planorbis needs to be investigated, which are still poorly known in this part of the world, for better management practices (Kohler et al., 2012). Molecular characterization must be adopted for the confirmation of invasive species (Kongim et al., 2015) as well as native species (Ng et al., 2016) especially showing high plasticity (Gustafson et al., 2014). The study regarding molecular characterization of Physids is the need of time as the cost of management of the invasive species will increase with the time elapse (Simberloff et al., 2013).

Certain snail species are bioindicators (Zeidan et al., 2020) however Physa is cosmopolitan in distribution (Albrecht et al., 2009; Altaf et al., 2017d). These snails are found in large number in the humid season i.e. from July through September as compared to the dry season i.e. December through February, however other abiotic factors also influence the distribution and abundance of these gastropods (Altaf et al., 2016; Qamar et al., 2017).
Shell structure has various characters which provide a primary guide line for identification of snails in taxonomic literature (Kerney and Cameron, 1979). The morphological characters of shell are misleading in this species identification due to phenotypic plasticity and convergent evolution (Albrecht et al., 2009) thereby making these quite unreliable. The molecular markers have been found important to assess the snail diversity (Hershler and Liu, 2004). The molecular markers are very helpful using DNA sequences for the correct and inexpensive identification of species (von Beeren et al., 2015) including 16S RNA and (COI) gene. The RAPD markers revealed genetic diversity more effectively as compared to the COI which are species specific markers (Thaewnon-Ngiw et al., 2004). Secondly species specific markers for molluscs have not been much reported due to which species characterization and genetic diversity revolved around RAPD markers in the last twenty years (Altaf et al., 2017a). The genetic diversity within three species reported in this study has been carried out for the first time in this region which will be useful for management practice of the invasive species of Physa acuta.

\section{Materials and Methods}

\subsection{Study area and sampling sites}

The sampling has been carried out in suburbs of different districts of Central Punjab $31^{\circ} \mathrm{N} 72^{\circ} \mathrm{N}$ (Figure 1). The snails from the different water bodies of the agroecosystem of

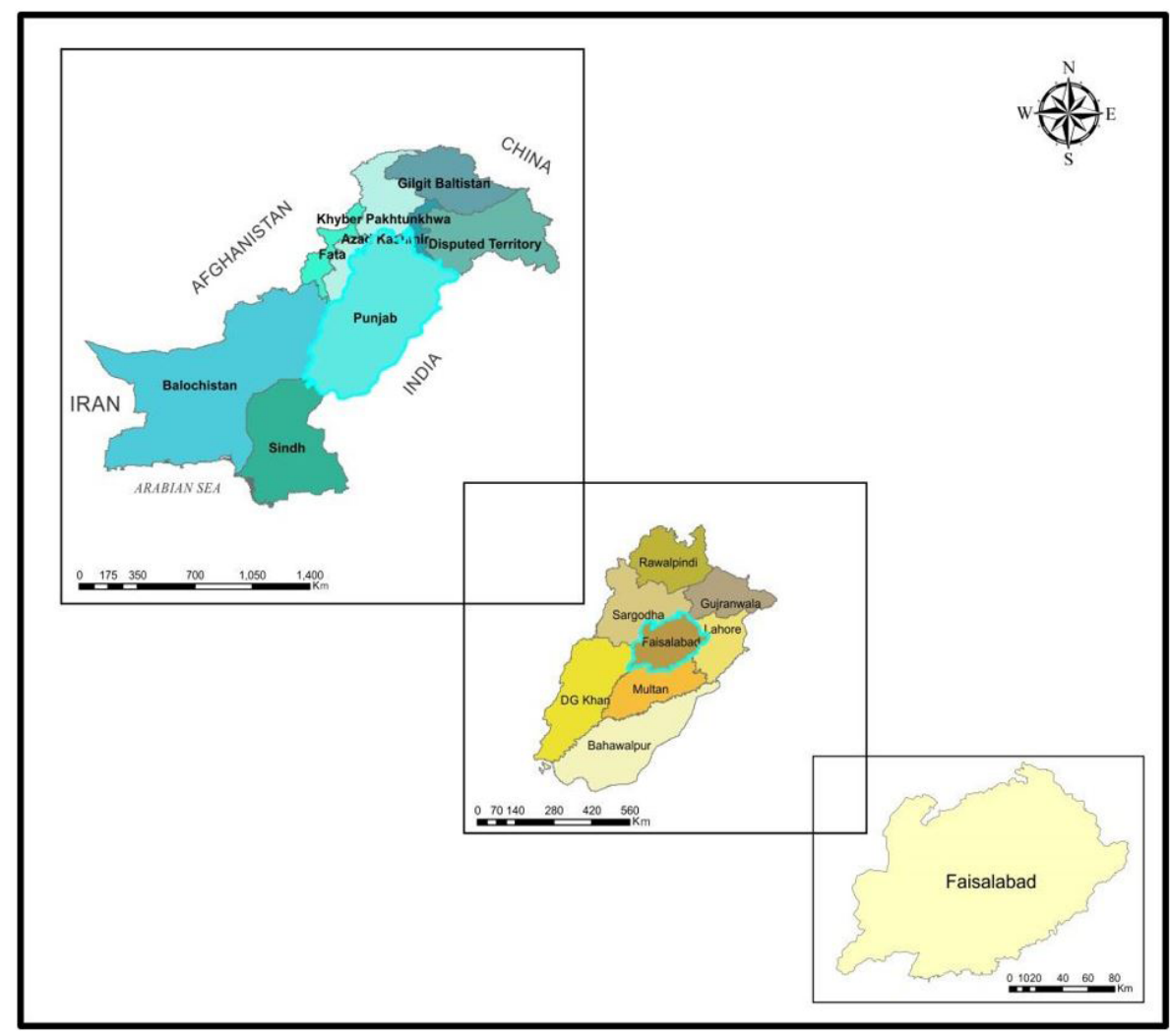

Figure 1. Central Punjab, Pakistan. 
the Central Punjab were collected by random sampling during the months of October 2017 to March 2018, by using hand-picking methods from irrigation canals of Faisalabad. Sixty two villages were selected randomly on the using lottery method (Figure 2). Every village was visited once during this period, at the dawn or dusk. The point of irrigation canals with the vegetation/tree cover were keenly observed for an hour to check the presence of species specimens for collection. The Physids species were handpicked for an hour from each village, on site identifications upto genus was carried out followed by the storage of these snail species in small specimen bottles. The stored samples were brought to the lab for preservation in $99.9 \%$ ethyl alcohol. All the specimen bottles were labelled with the collectors name, date, ecological information (Table 1).

\section{Morphometric Analysis}

The snail samples were identified with the help of keys and the diagrams given by Albrecht et al. (2009), Afshan et al. (2013), Dillon Junior and Jacquemin (2015). The picture of each snail was taken by photocamera following procedures adopted by Altaf et al. (2017b) (Figure 3).

\subsection{Genomic DNA extraction}

Total genomic DNA extraction from snail samples was done by following the CTAB method as described by Altaf et al. (2017a). The $15 \mathrm{ng} / \mathrm{ml}$ working dilutions DNA samples were made after measuring its concentration using Nanodrop (Sigma USA).

\subsection{Molecular analysis}

Total of fifteen decamers (Genelink Co. USA) were selected, based on their polymorphic amplification reported by Altaf et al.2017 . PCR amplification was carried out (PeqLab USA) using optimized concentration. of template DNA, 10X PCR buffer, $\mathrm{MgCl}_{2}$, dNTPs, primer and Taq DNA polymerase (MBI, Ferments, Vinius, Lithuania). The PCR amplification profile was used as $94 \mathrm{C}$ for $5 \mathrm{~min}$ following 40 cycles each of $94^{\circ} \mathrm{C}$ for 1 minutes, $36^{\circ} \mathrm{C}$ for $1 \mathrm{~min}, 72^{\circ} \mathrm{C}$ for $2 \mathrm{~min}$ and final extension at $72^{\circ} \mathrm{C}$ for $10 \mathrm{~min}$. The PCR products were resolved on $1.2 \%(\mathrm{w} / \mathrm{v})$ agarose gel stained with Ethidium bromide at $90 \mathrm{~V}$ for minutes and visualized

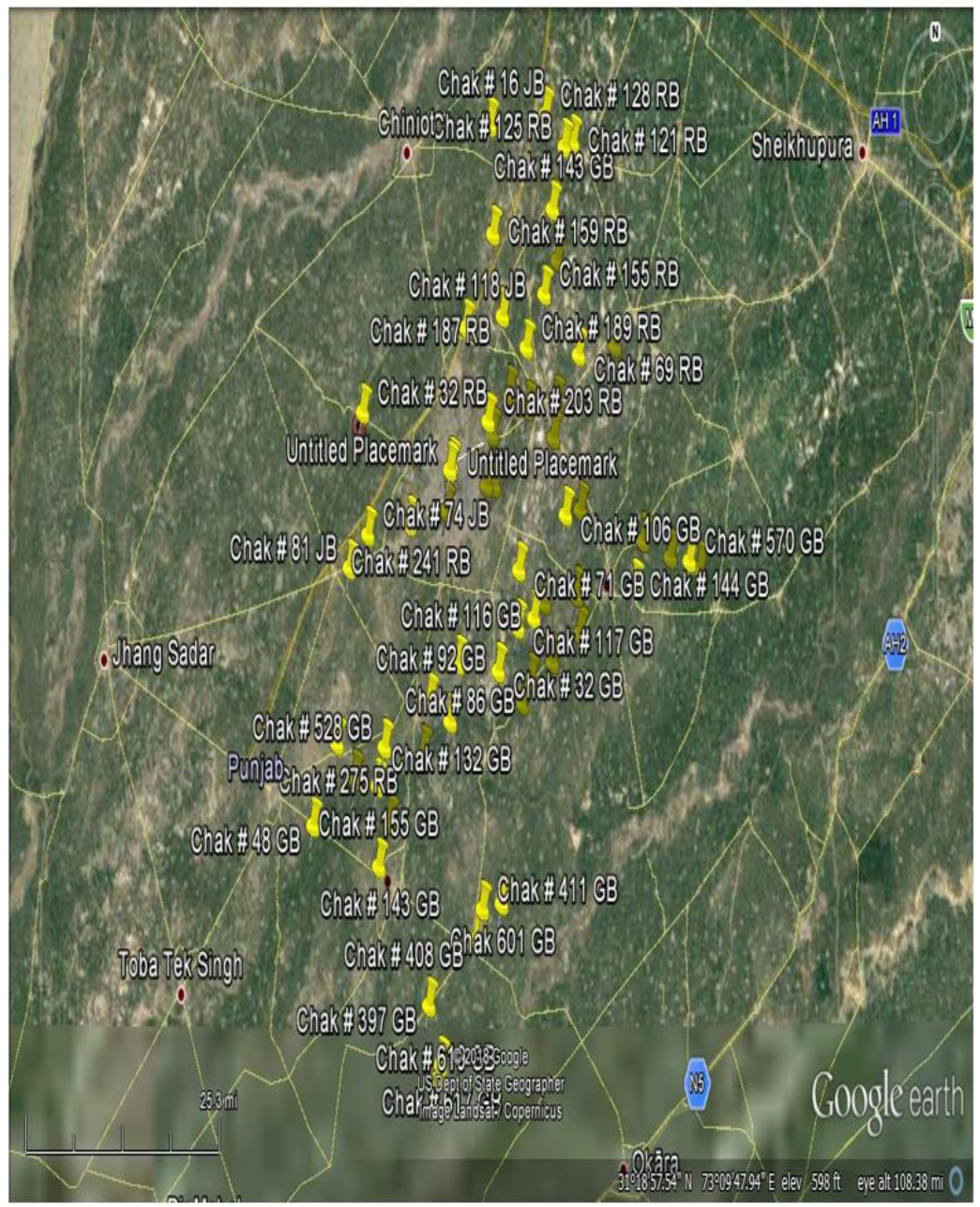

Figure 2. Sampling sites in Punjab. 
Table 1. Distributions of species of snails belonging to genus Physa in district Faisalabad.

\begin{tabular}{|c|c|c|c|c|}
\hline Sr. no. & Villages & Physa fontinalis & Physa acuta & Physa gyrina \\
\hline 1 & $23 \mathrm{~GB}$ & YES & - & - \\
\hline 2 & 26 GB & - & YES & - \\
\hline 3 & $32 \mathrm{~GB}$ & YES & YES & YES \\
\hline 4 & 34 GB & - & - & - \\
\hline 5 & 35 GB & - & - & - \\
\hline 6 & $48 \mathrm{~GB}$ & - & YES & - \\
\hline 7 & 55 GB & - & - & - \\
\hline 8 & $63 \mathrm{~GB}$ & - & YES & - \\
\hline 9 & $68 \mathrm{~GB}$ & - & YES & YES \\
\hline 10 & $71 \mathrm{~GB}$ & - & - & - \\
\hline 11 & 86 GB & - & YES & - \\
\hline 12 & 92 GB & - & - & - \\
\hline 13 & $106 \mathrm{~GB}$ & - & - & - \\
\hline 14 & $116 \mathrm{~GB}$ & - & - & - \\
\hline 15 & 117 GB & - & - & - \\
\hline 16 & $132 \mathrm{~GB}$ & YES & - & - \\
\hline 17 & $137 \mathrm{~GB}$ & - & YES & - \\
\hline 18 & $143 \mathrm{~GB}$ & - & - & - \\
\hline 19 & $146 \mathrm{~GB}$ & - & - & - \\
\hline 20 & $148 \mathrm{~GB}$ & - & - & - \\
\hline 21 & 155 GB & - & - & - \\
\hline 22 & $397 \mathrm{~GB}$ & YES & - & - \\
\hline 23 & 408 GB & - & YES & - \\
\hline 24 & $411 \mathrm{~GB}$ & YES & - & - \\
\hline 25 & $528 \mathrm{~GB}$ & - & - & - \\
\hline 26 & $531 \mathrm{~GB}$ & - & - & - \\
\hline 27 & $570 \mathrm{~GB}$ & - & - & - \\
\hline 28 & $601 \mathrm{~GB}$ & - & - & - \\
\hline 29 & 617 GB & - & - & - \\
\hline 30 & 619 GB & YES & - & - \\
\hline 31 & 632 GB & - & - & - \\
\hline 32 & 645 GB & YES & - & - \\
\hline 33 & 649 GB & YES & - & - \\
\hline 34 & 659 GB & - & - & - \\
\hline 35 & $69 \mathrm{RB}$ & - & - & - \\
\hline 36 & $71 \mathrm{RB}$ & - & YES & - \\
\hline 37 & $93 \mathrm{RB}$ & - & - & - \\
\hline 38 & $106 \mathrm{RB}$ & YES & - & - \\
\hline 39 & 118 RB & - & - & - \\
\hline 40 & $121 \mathrm{RB}$ & YES & - & - \\
\hline 41 & $123 \mathrm{RB}$ & - & - & - \\
\hline 42 & $125 \mathrm{RB}$ & - & YES & - \\
\hline 43 & $128 \mathrm{RB}$ & YES & - & - \\
\hline
\end{tabular}


Table 1. Continued...

\begin{tabular}{ccccc}
\hline Sr. no. & Villages & Physa fontinalis & Physa acuta & Physa gyrina \\
\hline 44 & $143 \mathrm{RB}$ & - & YES & - \\
45 & $148 \mathrm{RB}$ & YES & - & - \\
46 & $155 \mathrm{RB}$ & - & - & - \\
47 & $159 \mathrm{RB}$ & - & - & - \\
48 & $187 \mathrm{RB}$ & - & - & - \\
49 & $189 \mathrm{RB}$ & YES & YES & - \\
50 & $198 \mathrm{RB}$ & - & - & - \\
51 & $200 \mathrm{RB}$ & - & YES & - \\
52 & $203 \mathrm{RB}$ & - & - & - \\
53 & $204 \mathrm{RB}$ & - & YES & - \\
54 & $217 \mathrm{RB}$ & YES & - & - \\
55 & $222 \mathrm{RB}$ & - & - & - \\
56 & $241 \mathrm{RB}$ & - & Yes & - \\
57 & $275 \mathrm{RB}$ & - & - & - \\
58 & $16 \mathrm{JB}$ & $32 \mathrm{JB}$ & - & - \\
59 & $74 \mathrm{JB}$ & $81 \mathrm{JB}$ & - & - \\
60 & $118 \mathrm{JB}$ & - & \\
\end{tabular}

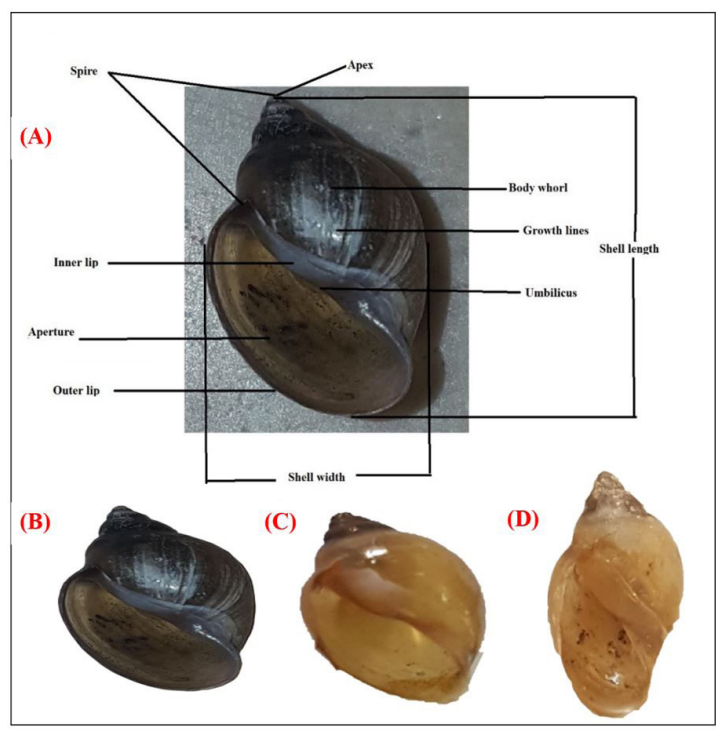

Figure 3. (A) Morphological Characteristics of Snails of Genus Physa (B) Physa acuta (C) Physa fontinalis (D) Physa gyrina.

by the gel doc system (SynGen, UK). Total of four SSR primers were used for genetic diversity estimation of snails. The 20ul SSR (PCR) mixture contained 0.2ul Taq DNA polymerase, 2.5ul PCR buffer (10X), 3ul $\mathrm{MgCl}_{2}$ (25mM), 5 ul of dNTPs and 3 ul template DNA, 2.5 of each forward and reverse primer and final volume of $20 \mathrm{ul}$ of reaction mixture was made by adding $\mathrm{d}_{3} \mathrm{H}_{2} \mathrm{O}$. The amplification profile of PCR comprises 30 cycles $94 \mathrm{C}$ for $5 \mathrm{~min}$ following 30 cycles each of $94^{\circ} \mathrm{C}$ for 1 minutes, $60^{\circ} \mathrm{C}$ for 30 seconds, $72^{\circ} \mathrm{C}$ for $1 \mathrm{~min}$ and final extension at $72^{\circ} \mathrm{C}$ for $10 \mathrm{~min}$.

\subsection{Data analysis}

The molecular data was analyzed using popgen 32 (Ver. 1.44) (Yeh et al., 1999). Principal component analysis and analysis of molecular variance (AMOVA) was done using the PAST software Hammer et al.(2001). The PIC value of polymorphic primer was calculated as devised by Anderson et al. (1993). PICi = $1-\sum$ P2ij (where pij is frequency of the jth allele for locus i). The genetic similarity between three snail species was calculated by following the methodology adopted by Nei (1973). Based on the genetic similarities the genetic relationship among the snail species was developed by an unweighted pair group method of arithmetic averages (UPGMA).

\section{Results}

All three species of genus Physa i.e $P$. fontinalis, $P$. acuta and $P$. gyrina were characterized by employing RAPD.

\subsection{RAPD PCR analysis}

Total of 15 RAPD primers were amplified out of which eight primers (Table 1) showed polymorphic banding pattern whereas seven RAPD primers showed monomorphic amplification and were excluded from the results. All the 
PCR amplification was done in triplicate to ensure the consistency of the RAPD amplification. Good amplification of all the eight RAPD primers was observed. The RAPD bands primers were scored which were generated by the primers and were found polymorphic across the three species. The average NPB (number of polymorphic bands) value was $30.37 \%$ of the three Physid species. All three genotypes of genus Physa produced 79 loci out of which 24 loci were found polymorphic. The primer GL-4 showed maximum polymorphism whereas minimum polymorphism was observed in the amplification of GK 03. The primer GL-02 produced maximum number i.e 13 while minimum number of loci were amplified by GL-05 i.e. 5 (Table 2).

Similarity matrix (Table 3 ) gave the genetic similarities among different Physa species. Maximum genetic similarities was observed between Physa gyrina and Physa acuta while lowest genetic similarities was observed between Physa acuta and Physa fontinalis. The polymorphism percentage ranged from $9.09 \%$ to $50 \%$ among the three genotypes of snail under study. Cluster analysis (Figure 4) shows the genetic relationship among three genotypes. It shows that Physa gyrina and Physa acuta are genetically close species as compared to Physa fontinalis. It was concluded that Physa gyrina and Physa acuta clustered together showing 77\% genetic similarity while the members of this Physa fontinalis have the genetic

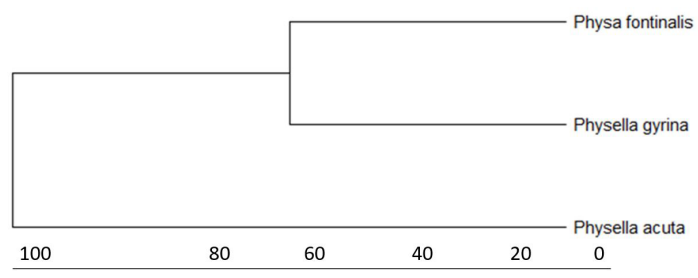

Figure 4. Dendrogram showing relationship among three Physa species. similarity of 70 percent with Physa acuta and 74 percent with Physa gyrina and Physa fontinalis.

\subsection{SSR analysis}

Total of four SSR primers were used to amplify the genomic DNA of three species of genus Physa and there was no amplification observed.

\section{Discussion}

Physa acuta is an invasive species and found in large numbers in irrigation canals of Central Punjab. All three species of genus Physa i.e P. fontinalis, P. acuta and P. gyrina were characterized by employing RAPD. It was observed that eight RAPD decamers showed good amplification and useful insight regarding genetic polymorphism as compared to the COI markers (Thaewnon-Ngiw et al., 2004). The Physid species mostly breed by selfing rather than cross fertilization which might be one of the reason of less polymorphism i.e. $30.37 \%$, however polymorphism percentage in Pila snails was $90.91 \%$ which have been reported to breed through cross fertilization. RAPD markers have been found to exhibit more genetic polymorphism as compared to the $\mathrm{COI}$ in apple snails, which might be due to the female founder effects. The RAPD markers revealed genetic diversity more effectively as compared to the COI which are species specific markers (Thaewnon-Ngiw et al., 2004). Few studies were carried out for genus Pseudamnicola (Delicado et al., 2015) and Hydrobiidae (Delicado et al., 2016) which showed similar polymorphism among species. Moreover, genetic diversity based on RAPD analysis depends on sharing of RAPD-amplified fragments and are scored in electrophoresis. The possibility of comigration of RAPD fragments having similar sizes but different sequences cannot be excluded. Therefore, homology of comigrating fragments should be further verified by sequencing and can further reveal.

Table 2. Genetic polymorphism revealed by RAPD(PCR) analysis.

\begin{tabular}{|c|c|c|c|c|c|}
\hline Sr No. & Primer Name & Sequence $\left(5^{\prime}-3^{\prime}\right)$ & TNB $^{1}$ & $\mathbf{N P L}^{2}$ & Polymorphism\% \\
\hline 1. & GL Decamer L-02 & TGGGCGTCAA & 13 & 3 & $23.07 \%$ \\
\hline 2. & GL Decamer L-04 & GACTGCACAC & 10 & 7 & $70 \%$ \\
\hline 3. & GL Decamer L-05 & ACGCAGGCAC & 5 & 1 & $20 \%$ \\
\hline 4. & GL Decamer L-08 & AGCAGGTGGA & 16 & 2 & $12.5 \%$ \\
\hline 5. & GL Decamer A-02 & TGCCGAGCTG & 8 & 3 & $37.5 \%$ \\
\hline 6. & GL Decamer A-03 & AGTCAGCCAC & 10 & 5 & $50 \%$ \\
\hline 7. & GL Decamer K-01 & CATTCGAGCC & 6 & 2 & $33.33 \%$ \\
\hline 8. & GL Decamer K-03 & CCAGCTTAGG & 11 & 1 & $9.09 \%$ \\
\hline Total & & & 79 & 24 & 30.37 \\
\hline Mean & & & 9.88 & 3 & \\
\hline Variance & & & 12.88 & 4.28 & \\
\hline
\end{tabular}

${ }^{1} \mathrm{TNB}=$ Total number of bands; ${ }^{2} \mathrm{NPL}=$ Number of polymorphic loci. 
Table 3. Similarity Matrix of genus Physa.

\begin{tabular}{cccc}
\hline Species & P. acuta & P. fontinalis & P. gyrina \\
\hline P. acuta & $* * *$ & 0.7419 & 0.7742 \\
P. fontinalis & 0.2985 & $* * *$ & 0.7097 \\
P. gyrina & 0.2559 & 0.3429 & $* * *$ \\
\hline
\end{tabular}

Nei's genetic identity (above diagonal) and genetic distance (below diagonal). ${ }^{* * *}$ denotes as $100 \%$ similarity as both are the same organisms used in this study.

This study can further lead to reveal the invasive range of $P$. acuta along with its invasion history and phylogenetics structure using other markers i.e. cox $1+16 \mathrm{~S}$, cox 1 and $16 \mathrm{~S}$ which indicated that $P$. acuta genetically related to P. spelunca (Ebbs et al., 2018). The P. acuta has been held responsible for the decline of the $P$. fontinalis where increase in temperature has been found as the driving force (Früh et al., 2015). In the present study, we used this technique to examine genetic diversity of the three species of the genus Physa in Faisalabad Pakistan. In future these RAPD markers can be converted into sequence characterized amplified regions or SCAR through cloning and can be further sequenced for the development of the Physa species markers. Further the two markers can be used together to identify the introduced and native species in Pakistan. The Physid species have been found to have a negative interaction with other species of the region (Altaf et al., 2017c) which might be due to the phenomenon of antibiosis or ammenalism. The molecular characterization of Physid species is extremely important as we have found potent bioactive substances showing antibacterial activity (Altaf et al., 2018) and antifungal and antiviral activity (unpublished data).

\section{Conclusion}

The species specific markers are extremely important for the characterization as it will not only be important for the management of the invasive species such as $P$. acuta.

\section{Acknowledgements}

The authors acknowledge the University research grant by Government College University Faisalabad for carrying out the research activities.

\section{References}

AFSHAN, K., BEG, M. A., AHMAD, I., AHMAD, M. M., and QAYYUM, M., 2013. Freshwater snail fauna of Pothwar region, Pakistan. Pakistan Journal of Zoology, vol. 45, no. 1, pp. 277-233.

ALBRECHT, C., KROLL, O., MORENO TERRAZAS, E. and WILKE, T., 2009. Invasion of ancient Lake Titicaca by the globally invasive Physa acuta (Gastropoda: Pulmonata: Hygrophila). Biological Invasions, vol. 11, no. 8, pp. 1821-1826. http://dx.doi.org/10.1007/ s10530-008-9360-9.
ALTAF, J., QURESHI, N.A. and SIDDIQUI, M.J.I., 2017a. Genetic diversity analysis of snail species (Mollusca: Gastropoda) using molecular marker technology. Journal of Biodiversity and Environmental Sciences., vol. 10, no. 1, pp. 26-35.

ALTAF, J., QURESHI, N.A. and SIDDIQUI, M.J.I., 2017b. Taxonomic studies on the occurrence of the snails (Mollusca: Gastropods) in the agroecosystem. Journal of Biodiversity and Environmental Science, vol. 10, no. 1, pp. 240-252.

ALTAF, J., QURESHI, N.A. and SIDDIQUI, M.J.I., 2017c. Interaction of snail species in the agroecosystem. Journal of Biodiversity and Environmental Science, vol. 10, no. 1, pp. 169-182.

ALTAF, J., QURESHI, N.A. and SIDDIQUI, M.J.I., 2017d. Terrestrial snails as bioindicators of environmental degradation. Journal of Biodiversity and Environmental Science, vol. 10, pp. 253-264.

ALTAF, J., QURESHI, N.A., RAZA, S.H. and SIDDIQUI, M.J.I., 2016. Assessment of diversity and distribution of Snails (Mollusca: Gastropoda) in the Agroecosystem of Faisalabad, Pakistan. Journal of Biodiversity and Environmental Sciences., vol. 8, no. 1, pp. 17-33.

ALTAF, J., RASOOL, M.H., AKHTAR, S., MANZOOR, M., YOUNAS, T., ANSARI, B., AHMAD, G., JABEEN, F., ALI, M. and MUNIR, R., 2018. Comparative evaluation of antibacterial activity of foot muscle extracts from genus Physa and genus Ceciloides (Mollusca: gastropoda). Pakistan Journal of Pharmaceutical Sciences, vol. 31, no. 4, suppl, pp. 1555-1563. PMid:30058548.

ANDERSON, J. A., CHURCHILL, G. A., AUTRIQUE, J. E., TANKSLEY, S. D., and SORRELLS, M. E., 1993. Optimizing parental selection for genetic linkage maps. Genome, vol. 36, no. 1, pp. 181-186.

BOUSSET, L., POINTIER, J.P., DAVID, P. and JARNE, P., 2013. Neither variation loss, nor change in selfing rate is associated with the worldwide invasion of Physa acuta from its native North America. Biological Invasions, vol. 16, no. 8, pp. 1769-1783. http://dx.doi.org/10.1007/s10530-013-0626-5.

BOUSSET, L., POINTIER, J.P., DAVID, P. and JARNE, P., 2014. Neither variation loss, nor change in selfing rate is associated with the worldwide invasion of Physa acuta from its native North America. Biological Invasions, vol. 16, no. 8, pp. 1769-1783. http://dx.doi.org/10.1007/s10530-013-0626-5.

DELICADO, D., MACHORDOM, A. and RAMOS, M.A., 2015. Effects of habitat transition on the evolutionary patterns of the microgastropod genus Pseudamnicola (Mollusca, Hydrobiidae). Zoologica Scripta, vol. 44, no. 4, pp. 403-417. http://dx.doi. org/10.1111/zsc.12104.

DELICADO, D., PESTIC, V. and GLOER, P., 2016. Unraveling a new lineage of Hydrobiidae genera (Caenogastropoda: Truncatelloidea) from the Ponto-Caspian region. European Journal of Taxonomy, no. 208, pp. 208. http://dx.doi.org/10.5852/ ejt.2016.208.

DILLON JUNIOR, R.T. and JACQUEMIN, S.J., 2015. The Heritability of Shell Morphometrics in the Freshwater Pulmonate Gastropod Physa. PLoS One, vol. 10, no. 4, pp. e0121962. http://dx.doi. org/10.1371/journal.pone.0121962. PMid:25876155.

EBBS, E.T., LOKER, E.S. and BRANT, S.V., 2018. Phylogeography and genetics of the globally invasive snail Physa acuta Draparnaud 1805 , and its potential to serve as an intermediate host to larval digenetic trematodes. BMC Evolutionary Biology, vol. 18, no. 1, pp. 103. http://dx.doi.org/10.1186/s12862-018-1208-z. PMid:29969987.

FRUH, D., HAASE, P. and STOLL, S., 2015. Temperature drives asymmetric competition between alien and indigenous freshwater snails (Physa acuta vs. Physa fontinalis). Aquatic Sciences, vol. 79, pp. 187-195. https://doi.org/10.1007/s00027016-0489-9. 
GUSTAFSON, K.D., KENSINGER, B.J., BOLEK, M.G. and LUTTBEG, B., 2014. Distinct snail (Physa) morphotypes from different habitats converge in shell shape and size under common garden conditions. Evolutionary Ecology Research, vol. 16, pp. 77-89.

HAMMER, Ø., HARPER, D.A. and RYAN, P.D., 2001. PAST: paleontological statistics software package for education and data analysis. Palaeontologia Electronica, vol. 4, no. 1, pp. 1-9.

HERSHLER, R. and LIU, H.P., 2004. A molecular phylogeny of aquatic gastropods provides a new perspective on biogeographic history of the Snake River region. Molecular Phylogenetics and Evolution, vol. 32, no. 3, pp. 927-937. http://dx.doi.org/10.1016/j. ympev.2004.02.012. PMid:15288067.

KAKAR, S. D, KAMRAN, K., ESSOTE, S.A., IQBAL A. and ALI, M., 2017. Species diversity of freshwater snails (Mollusca: Gastropoda) in different sites of Balochistan province of Pakistan. International Journal of Biosciences, vol. 10, no. 3, pp. 251-259. http://dx.doi. org/10.12692/ijb/10.3.251-259.

KERNEY, M.P. and CAMERON, R.A.D., 1979. A field guide to the land snails of Britain and north-west Europe. Oryx, vol. 15, no. 5 , pp. 508-509. http://dx.doi.org/10.1017/S003060530002932X.

KOHLER, F., SEDDON, M., BOGAN, A.E., DO, V.T., SRI-AROON, P. and ALLEN, D.J., 2012. The status and distribution of freshwater molluscs of the Indo-Burma region. In: D.J. ALLEN, K.G. SMITH and W.R.T. DARWALL, eds. The Status and Distribution of Freshwater Biodiversity in Indo-Burma. Switzerland: IUCN, pp. 66-89

KONGIM, B., PANHA, S. and SUTCHARIT, C., 2015. Cytotaxonomy of unionid freshwater mussels (Unionoida, Unionidae) from northeastern Thailand with description of a new species. ZooKeys, vol. 514, no. 514, pp. 93-110. http://dx.doi.org/10.3897/ zookeys.514.8977. PMid:26261434.

NEI, M., 1973. Analysis of gene diversity in subdivided populations. Proceedings of the National Academy of Sciences of the United States of America, vol. 70, no. 12, pp. 3321-3323. http://dx.doi. org/10.1073/pnas.70.12.3321. PMid:4519626.

NG, T.H., LIEW, J.H., SONG, J.Z.E. and YEO, D.C.J., 2016. First record of the cryptic invader Pyrgophorus platyrachis Thompson, 1968 (Gastropoda: Truncatelloidea: Cochliopidae) outside the Americas. BioInvasions Records, vol. 5, no. 2, pp. 75-80. http:// dx.doi.org/10.3391/bir.2016.5.2.03.

NG, T.H., LIMPANONT, Y., CHUSONGSANG, Y., CHUSONGSANG, P. and PANHA, S., 2018. Correcting misidentifications and first confirmation of the globally-invasive Physa acuta Draparnaud, 1805 (Gastropoda: Physidae) in Thailand and Laos. BioInvasions Records, vol. 7, no. 1, pp. 15-19. http://dx.doi.org/10.3391/ bir.2018.7.1.03.
QAMAR, S.U.R., SAIF, A. and ALTAF, J., 2017. Identification of the species of genus Zootecus on the basis of morphology. Journal of Biodiversity and Environmental Sciences, vol. 11, no. 3, pp. 122-127.

SIMBERLOFF, D., MARTIN J. L., GENOVESI, P., MARIS, V., WARDLE, D. A., ARONSON, J., COURCHAMP, F., GALIL, B, GARCIA-BERTHOU E, PASCAL M, PYSEK, P., SOUSA, R., TABACCHI, E., and VILÀ, M., 2013. Impacts of biological invasions: what's what and the way forward. Trends in Ecology and Evolution, vol. 28, no. 1, pp. 58-66. https://doi.org/10.1016/j.tree.2012.07.013.

THAEWNON-NGIW, B., KLINBUNGA, S., PHANWICHIEN, K., SANGDUEN, N., LAUHACHINDA, N. and MENASVETA, P., 2004. Genetic diversity and molecular markers in introduced and Thai native apple snails (Pomacea and Pila). Journal of Biochemistry and Molecular Biology, vol. 37, no. 4, pp. 493-502. http://dx.doi. org/10.5483/BMBRep.2004.37.4.493. PMid:15469739.

TURNER, A.M. and MONTGOMERY, S.L., 2009. Hydroperiod, predators and the distribution of physid snails across the freshwater habitat gradient. Freshwater Biology, vol. 54, no. 6, pp. 1189-1201. http://dx.doi.org/10.1111/j.1365-2427.2009.02168.x.

VAN LEEUWEN, C.H., HUIG, A.N., VAN DER VELDE, G., VAN ALEN, T.A., WAGEMAKER, C.A.M., SHERMAN, C.D.H., KLAASSEN, M. and FIGUEROLA, J., 2013. How did this snail get here? Several dispersal vectors inferred for an aquatic invasive species. Freshwater Biology, vol. 58, no. 1, pp. 88-99. http://dx.doi. org/10.1111/fwb.12041.

VON BEEREN, C., STOECKLE, M. Y., XIA, J., BURKE, G., \& KRONAUER, D. J. C., 2015. Interbreeding among deeply divergent mitochondrial lineages in the American cockroach (Periplaneta americana). Scientific Reports, vol. 5, pp. 8297. http://dx.doi.org/10.1038/ srep08297.

WETHINGTON, A.R. and LYDEARD, C., 2007. A molecular phylogeny of Physidae (Gastropoda: Basommatophora) based on mitochondrial DNA sequences. The Journal of Molluscan Studies, vol. 73, no. 3, pp. 241-257. http://dx.doi.org/10.1093/ mollus/eym021.

ZEIDAN, G.C., FREITAS, L.A., SANTOS, G.B.M., SILVA-NETO, E.M. and BOEHS, G., 2020. Morphometric analysis of Littoraria angulifera (Caenogastropoda) in estuarine regions of northeastern Brazil. Brazilian Journal of Biology = Revista Brasileira de Biologia, vol. 80, no. 2, pp. 424-430. http://dx.doi.org/10.1590/1519-6984.214187. PMid:31482972.

YEH, F. C., YANG, R., and BOYLE, T., 1999. [viewed 30 June 2020]. PopGen 1.0. [online]. Available from: http://cc.oulu.fi/ *jaspi/ popgen/popgen.htm. 